cognizancejournal.com

OSAWARU AIGBEOVBIOSA TERRY, Cognizance Journal of Multidisciplinary Studies, Vol.1, Issue.4, April 2021, pg. 13-29

\title{
THE BURDEN OF HISTORY AND THE ANTILLEAN'S QUEST FOR HIS DISTINCTIVE IDENTITY
}

\author{
OSAWARU AIGBEOVBIOSA TERRY, Ph.D \\ DEPARTMENT OF FOREIGN LANGUAGES, FACULTY OF ARTS, UNIVERSITY OF \\ BENIN, BENIN-CITY, NIGERIA \\ DOI: 10.47760/cognizance.2021.v01i04.002
}

\section{ABSTRACT}

One of the greatest burdens to bear is that of an unfavourable history. Its weight has a great deal of undertones that turn the existence of the persons involved into a psychologically distorted one. On this question of the burden of history, a collective approach has more far reaching psychological consequences for its bearers than that with an individualistic dimension. The former captures the reality of the Antillean people of Guadeloupe and Martinique, two overseas Departments of France. Our objective in this paper therefore is to painstakingly examine the Antillean's history, existence and space with a view to rationalizing the reactionary and innovative mentality amongst the Antillean people who seem to be racing against time in the search for their true identity, qualities and future projections.

KEYWORDS: Burden, History, Slave trade, Identity, Caribbean, Antillean, Africa, Landscape. 
cognizancejournal.com

OSAWARU AIGBEOVBIOSA TERRY, Cognizance Journal of Multidisciplinary Studies, Vol.1, Issue.4, April 2021, pg. 13-29

\section{INTRODUCTION}

History directly poses a problem in the French Caribbean regardless of the angle through which one attempts to approach it. Romouald Fonkoua ( $2006: 106$ ) ( The translation is ours.)

Despite more than one hundred and fifty years of freedom from slavery, it is an indisputable fact that slavery remains the most important historical event that dominates and conditions the psyche of the Antillean person. The entire Antillean population carries with it today scars of three centuries of slavery, characterized by economic exploitation, racial discrimination and mental enslavement. Mokwenye ( $2009: 135$ )

Contrary to rational expectations on the impossibility arising from its inherent and apparent inconceivable nature, interrogating the history of a people without a clearly defined 'past' can prove to be one of the most compelling and revealing experiences of literary and historical critics. The evidential basis of this assertion is even more striking when juxtaposed with the realities in the Francophone Caribbean Islands of Guadeloupe and Martinique. For as Romouald Fonkuoa rightly captures it about the people of these Islands :

Therefore if there is a recurrent topic in Caribbean literature, it is without doubt that of history or more precisely, absence of history. It motivates and justifies literary productions. ( $2006: 104$ ) The translation is ours.

Discovered respectively in 1493 and 1502 by Christopher Columbus, these Islands became gradually and largely populated by slaves captured from Africa between the sixteenth and nineteenth centuries. The dehumanization and the tabula rasa phenomenon that the slave suffered gave him an unclassifiable identity and left him with little or nothing to live or aspire for. The inhuman treatment, the racial prejudice against the black skin, the cultural and spiritual 


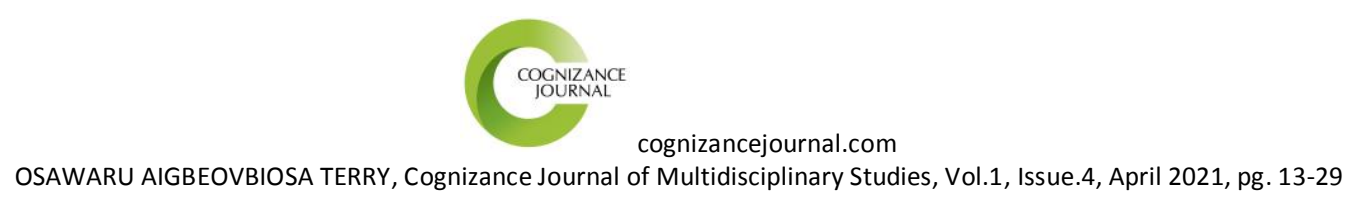

disconnect and the accomplice perception of the Caribbean landscape left a bitter pill for the Antillean to swallow. Having been declared free at the wake of the abolition of slave trade in the French Islands on the $27^{\text {th }}$ of April, 1848, the Antillean made some very striking and worrisome revelations about himself and his existence. Firstly, he discovered that despite the remarkable abolition of slavery, his status in the French Caribbean society still left much to be desired. He was still going to work more or less as a slave because the white ruling class retained economic and political power, necessitating the freed slaves to still work in the white man's sugarcane and banana plantations ( two agricultural produce principally identified with the French Caribbean. ) in order to earn a ( meagre ) living. He was also faced with the unpleasant reality that his black skin colour, apart from serving as a constant negative reminder of the sufferings, deprivation and humiliation of the slave trade era, was also a ticket for him to belong to the wretched of the Caribbean landscape owing to the blacks being far beneath the whites and the Mulattos ( descendants of slaves and white slave masters ) in the racial pecking order. Another revelation that dawned on him was in form of a double edged sword : on the one hand, he realized that he could no longer easily return and reintegrate himself in Africa, the continent of his ancestors, owing to his long duration of absence ( slave trade lasted for over three hundred years ) and the geographic distance between Africa and the French Caribbean Islands. On the other hand, he was convinced at the time that being a land that witnessed and facilitated the denigration of his being during the slave trade era, the French Caribbean Islands could not be transformed into serving henceforth as his permanent and definite abode of existence. To the Antillean, the colour of his skin, his land of birth, his slave past and, above all, his distorted, inglorious and fragmented history did not do him any good as they are all contributory factors to his history burden, one 
cognizancejournal.com

OSAWARU AIGBEOVBIOSA TERRY, Cognizance Journal of Multidisciplinary Studies, Vol.1, Issue.4, April 2021, pg. 13-29

which the Antillean is still engrossed with lifting. In other words, a race had been freed, but a society where they could blossom had not been clearly established. Régis Antoine ( 1992 ) explains this further :

The final abolition of slave trade in 1848 did not free black men and women from economic dependency, but it admitted them into French citizenship. p.231 (The translation is ours)

Maryse Condé ( 1977 ) lends her voice to this discourse as well :

Slave trade abolition was first and foremost to the advantage of the Mulattos especially as they are economically powerful (...) It is therefore inevitable that, faced with miserable and uneducated slaves, they constituted a domineering class. pp. 48-49. (The translation is ours)

In his quest to at least make his burden lighter, the Antillean has fine-tuned strategies geared towards redefining his existence following his own evaluative and conceptual standards. At inception, French Caribbean Islands were made up of Guyane, Haïti, Guadeloupe and Martinique. Having attained independence in 1804 through the relentless efforts of Toussaint Louverture, Haït ceased to be a French Overseas Department. Again research efforts are majorly focused on Guadeloupe and Martinique when discussing the Francophone Caribbean Islands to the exclusion of Guyane because Guyane did not become a French territory (until 1816) as early as Guadeloupe and Martinique (1635 ). Furthermore, Guyane is not in the shape of an Island and does not maintain Geographic proximity with the other two Islands. It is to this end that we crave indulgence here on the fact that Guadeloupe and Martinique will be retained as our primary focus in this study. 
cognizancejournal.com

OSAWARU AIGBEOVBIOSA TERRY, Cognizance Journal of Multidisciplinary Studies, Vol.1, Issue.4, April 2021, pg. 13-29

\section{PREAMBLE}

To begin our interrogation of the francophone Caribbean history, a concise approach to this study would be pertinent at this point. The francophone Caribbean discourse kicked off on a slave trade note. In order words, France's quest for economic dominance, political relevance and territorial expansion propelled her to colonize a part of the West Indies which is known today as the French Caribbean. Owing to the huge prospects of developing an economically viable overseas Department out of the Islands, France deemed it imperative to populate the region with Africans captured as slaves in a bid to recruit people that could carry out the strenuous job that working in the plantation de canne à sucre (sugarcane plantation) and la culture des banana (banana cultivation) entailed at the time. Being a slave entailed far more than just the farm work that initially gave rise to the forced shipment of Africans to the Islands, it also involved being deployed at the home front as a "domestique " ( house keeper ) 1. The Martinican writer, Roland Brival histirically captures the daily routine of the life of Macouba, a slave who serves as a major character in his novel La Montagne d'ébène, a description he presents thus :

He only takes a break from work from Saturday evening to Sunday evening in order to have time for the cleaning of the houses, water boilers, trains, pipes as well as mill servicing. p. 43

( The translation is ours )

(1) My usage of the French word "domestique" ( which is a pejorative way of referring to a house keeper ) instead of "employé de maison " (which is less demeaning ) underscores in a little way my intention to bring to the fore the dehumanization of the black man during the slave trade period. 
cognizancejournal.com

OSAWARU AIGBEOVBIOSA TERRY, Cognizance Journal of Multidisciplinary Studies, Vol.1, Issue.4, April 2021, pg. 13-29

The untold hardship and inhuman treatment suffered during the turbulent slave trade period coupled with the negative economic realities the abolition of slave trade further launched the freed slaves into made it incumbent on them to re-examine their existence in line with redefining where they truly belong. Having a historically traceable link with France, and believing that they had been assimilated into the French culture and way of life, some of the freed slaves succumbed to the dictates of this mentality by travelling to France where they expected that life would be more acceptable and decent. Julie Lirus summarizes this fact in the following words :

For majority of workers, job security, the continuous search for a job, an aggregation of several seasonal and fragmented activities result most of the time, in their not being able to secure their family's well-being. In addition, the movement towards the city, especially immigration to France, leads to a total disorganization of a lot of families. p.44

(The translation is ours.)

To the bewilderment of the Antilleans who migrated to France, no sooner had they settled in than they realized that their status as French citizens was still riddled with deep scars of marginalization and racial segregation. Glissant describes this phenomenon in Discours antillais this way :

The Caribbean migrant is ambiguous, he lives the life of a migrant, but he has a citizen status. (...) He feels he is a french citizen, but he suffers direct or indirect forms of racism. p.74

(The translation is ours.) 


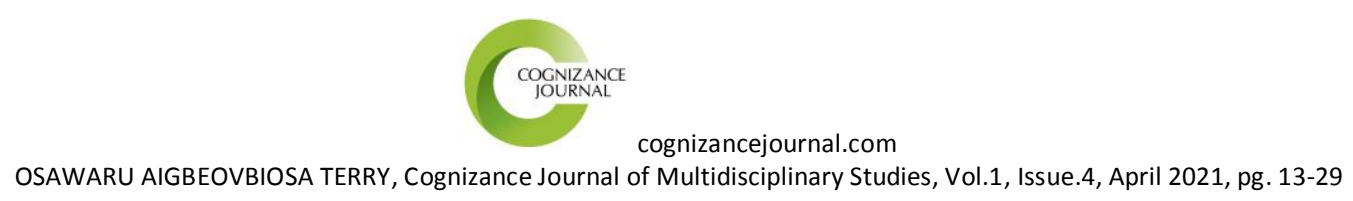

Not being able to fit into the french metropolitan society by achieving social equality at the time, the black Antillean people found life unbearable and subsequently concluded on re-igniting his African connection, this not just with a view to unlocking an integral part of his Being, but also re-invigorating his historical patrimony. At this point, owing to the deception that greeted his sojourn in France, and his quest to discover his true identity by getting over his deception in France, the Antillean saw his coming to Africa firstly as a panacea for unearthing his Africanity and secondly as a medium of situating himself where he felt he truly belonged at the wake of his rejection in France. Unfortunately, if the Antillean, based on his negative experiences in Africa, conceived the latter as a society that indirectly alienated and ostracized him, Africa had even a bigger and an unpleasant surprise for him. Owing to the huge expectations the Antillean had coming to Africa, he perceived Africa as being able to engender a very effective therapeutic machinery capable of cleansing him of all the humiliations he had been made to go through both in France and in the French Caribbeans. At this point, it is imperative to note that such mentality and believe were vigorously imbibed at the wake of the arrival of the first set of shipped slaves from Africa to the French Caribbean Islands. History in fact makes us to understand that, having been separated from their loved ones, affection, culture and above all, freedom, the captured slaves found in death, a viable and an assured avenue of fleeing slavery and returning to Africa. Corzani ( Tome 3, ) explains such suicides thus :

The ship having departed, and with the African coastline out of sight, the previously tenacious hope of escaping and going back to the definite land ( Africa ) off course started to fade. For many of the slaves, the solution was suicide. p.30

(The translation is ours.) 


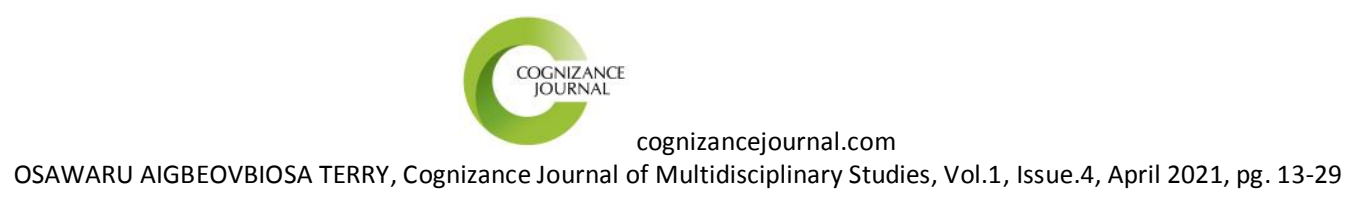

With the passage of time, the feeling of loyalty and believe in the African society could not however hold sway as it was confronted with the double coalition of a domineering french way of life and the geographic distance away from Africa. Nonetheless, having regained his freedom and having found life in France unbearable, the Antillean thought it expedient to relocate to Africa, his ancestral continent, about which he had heard so many glorious, heartwarming and triumphant episodes. However, the pre-slave trade Africa he heard about had undergone significant transformations to the extent that it was no longer congruent with the Antillean's expeditionary expectations. The Antilleans objectives in this regard quickly metamorphosed into a disconsolate situation. In other words, the cold reception he received made him unhappy and unsatisfied. In no time, this feeling snowballed into despair for the Antillean as a result of his not being able to integrate into an African system and way of life where he was perceived as unsuitable to the African ways and having a skin colour that was not dark enough. Illustrations of this era in the existence of the Caribbean man are well captured in francophone Caribbean literature. This is aptly represented in Maryse Condé's Hérémakhonon where the main character, Veronica, is seen to be lamenting her disappointment at the turn of events in Africa :

What irony ! I regretted my damaged identity, isn't it ? I have come here as a European traveller to destroy what is left of my personality. Running away from the alienated people in my Island of birth, I have come here ( Africa ) to suffer other forms of alienation. p. 237

( The translation is ours )

In the novel, Hérémakhonon, Veronica witnessed, first hand, the upheaval, the injustice and the corruption in the African society. Not being able to find peace and comfort that had necessitated her journey to Africa, she therefore flees the African continent out of frustration and disappointment. Another example of the Antilleans quest to resolve his history burden by way of 
conceiving Africa as a healing milieu is manifested in Myriam Warner-Vierya's Juletane. Juletane, a Guadeloupean living in France, falls in love with an African, Mamadou. Prior to the meeting, Juletane had been battling with psychological issues having a great deal to do with the indices ( her origin, her skin colour, her forefathers, her mystified identity, slave history and her poorly documented history ) of her past. Having obviously heard beautiful things about Africa as being the continent of her ancestors, Juletane sees her relationship with Mamadou as being divinely orchestrated. This explains why she was overwhelmed with joy at the opportunity to visit Africa in company of Mamadou :

I was so happy. I opened my mouth, but no sound came out. I was having a marvelous dream, Mamadou loves me and was going to take me with him to his country in Africa, where we would live. p.32

( The translation is ours )

To Juletane, it was a golden opportunity to revive her being by setting out to establish cultural linkages with Africa, her ancestral home. Unfortunately for Juletane, this huge dream quickly turns out to be a nightmarish and horrifying experience as she, upon arrival on the African continent, discovers that Mamadou already has a wife and that she is perceived as being a foreigner even by those she had earlier chosen to see as family:

My arrival on this African land of my fathers, I had imagined it in several ways, and now it has turned into a nightmare. I no longer wondered how I was going to be received by Mamadou's family ; sure that I was going to be an intruder, uninvited, relegated. The other woman was with her daughter, surrounded by relatives that had chosen her and was protecting her. While I would be there ridiculously lonely in their midst, I am the foreigner. p. 35

( The translation is ours ) 


\section{THE HISTORY BURDEN : THE FACTORS}

The Antillean is faced with the burden of history on many fronts; our study will touch on them with a view to finding the basis for the history burden from the Antillean's point of view ;

\section{The Landscape}

A major contributory factor to the Antillean's burden is that of the Caribbean landscape. Upon being sold to work as slaves, the captured Africans were forcefully taken to the Islands of Guadeloupe and Martinique ( the new world ). They, and their descendants after them, would spend about four centuries of their existence in these Islands. All the intricacies of the slave trade era, the dehumanization, the many years of slavery, the barbaric nature of nature the slaves were made to assume of themselves, the societal segregation, racial discriminations and the fact as well that all these transpired within the confines of the Caribbean space made the Antillean to perceive the Caribbean Islands as being inimical and toxic to his existential, emotional and psychological well-being. It could therefore be deduced that in the Antillean's quest for a redefinition of his personality, in his quest to forge for himself a whole new identity, culture and future, Francophone Caribbean Islands are adjudged by him to be an unsuitable feature of the proposed new dawn. This, added to the economic impasse for the black population of these islands, compels the Antillean to explore other horizons where life could be more befitting, accommodating and fair. 


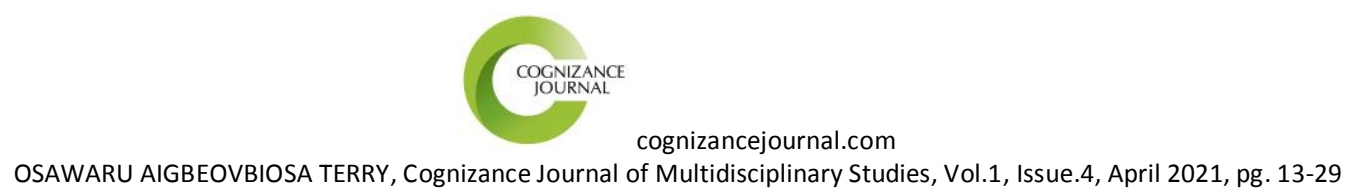

\section{The Black skin}

A very recognizable and striking factor that compounds the burden of history on the part of the Francophone Antillean is the colour of his skin ! A major topic of discussion, the black skin colour is, even today, considered by some Antilleans as repugnant and nauseating to his project of getting rid of his historically psychological trauma. During the slavery days, the black skin became synonymous with the inferiority of the black man in comparison with the white slave masters. It was also connected with a supposed uncivilized and barbaric nature of the blacks in the French Caribbean Islands. The black skin colour was also an indication and a symbol of a set of people perceived as 'the wretched of the earth' according to Frantz Fanon in his book Les Damnés de la terre. This negative perception viv-a-vis the black skin permeated the French Caribbean Islands principally during the slave trade period owing to the subjection of the blacks to the white ruling class. It therefore follows that in his quest for a well-defined future and strategies towards self-comprehension, the Antillean finds it difficult to come to terms or to appreciate the colour of his skin, which he sees as an impediment.

\section{Who am I ?}

Unarguably the most important question that is unfortunately yet to be satisfactorily answered in the Caribbean's ascendency. The Antillean still grapples with self-identification by way of being able to establish a tangible and traceable connection with his progenitors. Though not in doubt, the issue of African provenance in the existence of the Antillean people permeates in a psychologically traumatizing fashion every facet of the Caribbean reality. This dilemma calls into question the expected description of the Caribbean people as a transverse population linking 


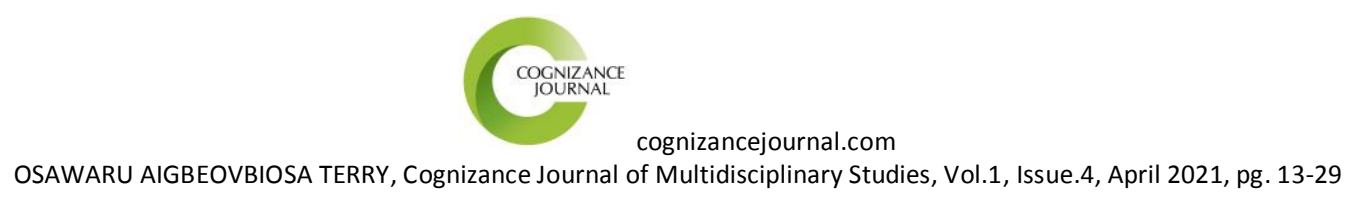

Africa with her diaspora. This owes, amongst other indices, to the long duration of slave trade and the racially mixed population of the Caribbean Islands. As the Caribbean population is largely made up of African, European and Asian descent, with the African lineage being a major tributary of the tripartite configuration and therefore played a central role in the eventual outcome of this 'human surgical laboratory' that the Guadeloupean and Martinican Islands currently represent.

In resolving the "who am I question ' most of the Antillean people prefer to downplay, or repudiate even, the African part of their relatively nascent ( cultural ) history as a people. Going forward, the Antillean would rather at best acknowledge a tangential relationship between his being and the African continent of his forefathers. Maryse Condé ( 1977, volume 2 ) testifies of this trivial and less significant acknowledgement that the Antillean expresses to the African continent :

It is known that Africa played a major role in the Antillean philosophy. One can accept that Africa was first and foremost present, alive and that the captured Africans will remain attached to her beyond time and distance (...) then gradually, Africa confronted with a double coalition of slave masters and religious leaders, in other words, by economic and spiritual powers, symbolize as a result the most shameful part of the Antillean's ascendency. The latter wished to bury it within them, and subsequently prove by every behavior that they have forgotten about Africa. p.38

(The translation is ours )

From a position of passionate and optimistic curiosity therefore, the Antillean has now drifted into a mentality of recoiling from the African continent. It is perhaps this distinction between Africa and the French Caribbeans. That Gisele Pineau, a Guadeloupean writer, set out to 


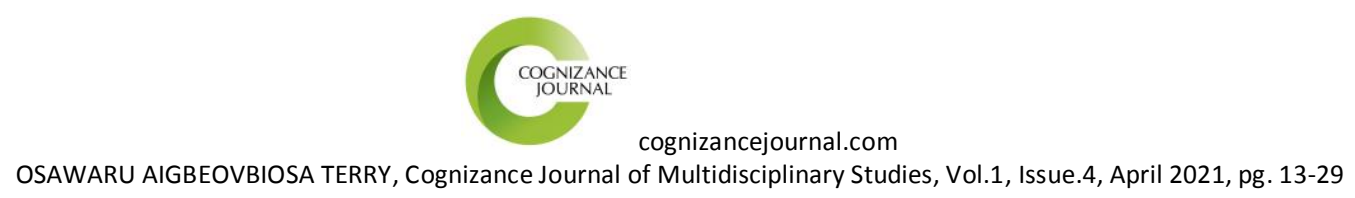

highlight in her novel ' Un Papillon dans la cite 'when she focused her literary commitment on bringing the polarization between Africans and Antilleans to the fore. The novel depicts a little girl's (Félicie) bewilderment at her mother's 'laisser-faire attitude towards her despite the fact that they had only just reunited after several years of living apart. Realizing that her mother's attention, love and care had shifted from her to her younger brother, Mimi, who was born during the period she was separated from her mother. Félicie expresses her disappointment thus :

Mummy's eyes were shining while she was caressing and whispering sweet words to her Mimi. Did she ever display such affection towards me before living me ten years earlier ? I had just reappeared in her life and she had shown me lesser attention compared to that of her Mimi who she sees every time for four good years now. p.35

( The translation is ours )

In this novel, Pineau undertakes to expose the fact that the gap now existing between Africa and the French Caribbean Islands should not only be evaluated on the strength of the distance that separates them, but should also be understood on the basis of the differences in ideology and mentality. Seemingly, Pineau's preoccupation in the novel is to establish symbolic representations viv-a-vis the manner in which some Antilleans have been somewhat ostracized from the African continent, in their understanding of the relationship between them and Africa, they perceive a total disregard of their being and their current personality and reality due to what they have metamorphosed into. In reaction therefore to their rejection in Africa, they have chosen to only acknowledge Africa as a part of their past, and nothing more. In this regard, Africa has nothing tangible to do with neither their present realities or future aspirations. 


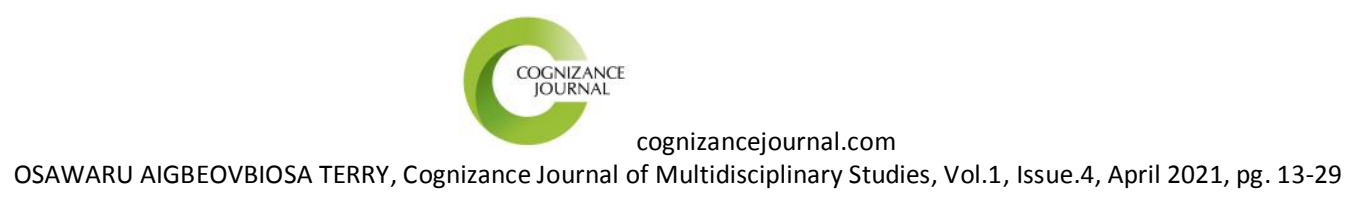

Mokwenye ( 2009 ) also set out to capture this Antillean mentality and feeling this way :

Africa may be the source of their racial origin, but they are no longer true Africans, and so it is necessary for them to play down their African connection in order to build up their new land. p. 160

Africa and the French Caribbeans are therefore two symbolic sides of a coin. What this means is that, in his existential progression and deliberate efforts to understand, define and project his personality, the Antillean is sparing no effort towards convincing himself and other concerned parties in his historical trajectory that the role of Africa in his ascendency can only be historical. Believing that he needs to forge ahead, let go of an inglorious past and resolve his huge history burden, the Antillean conceives disowning contemporary Africa as a prerequisite to this end. In addition, the Antillean currently sees Africa as a primitive, developmentally retarded and economically malnourished continent which only relevance to finding a lasting solution to his burden of history can only be by way of a cultural anchor which is pivotal to his renaissance project. Mokwenye ( 2013 ) expresses thus Africa's role in the Caribbean project :

It must be noted that Africa will continue to form a kind of cultural reference point for people of the black race all over the world, including those living in the Francophone Caribbean Islands. Even though the younger generation of Francophone Caribbean writers of the post Negritude period expressed this disappointment, the Caribbeans remain today Caribbean indigenes of African descent. p.127 
cognizancejournal.com

OSAWARU AIGBEOVBIOSA TERRY, Cognizance Journal of Multidisciplinary Studies, Vol.1, Issue.4, April 2021, pg. 13-29

\section{CONCLUSION}

The most worrisome of the inadequacies the Antillean faces till date remains the burden of his ruptured and inglorious history. Literary and historical researchers are still engrossed with demystifying the complicated and burden rippled history of the Guadeloupean and Martinican people. Being at the receiving end of the ripple effects of the burden of a distorted history owing to the ravages of the slave trade era, Guadeloupeans and Martinicans have been slowly but surely implementing strategies geared towards pulling level with other well established civilizations across the globe in their bid to redefine and set themselves free from every form of their history burden. To this end, they have adjudged it necessary to downplay their African patrimony owing to the constant negative reminder of the humiliating slavery past that Africa serves them. Other factors such as the Caribbean landscape, their subtle rejection and racial segregation by France and the black colour of their skin have been evaluated to have negative effects on the Caribbean personality rebuilding project, this, from the perspective of the Antillean of colour. Overall, the Antillean's energy is dissipated along the lines of flinching from Africa more than anything else. But as was canvassed, the Antillean's desire to reduce or eliminate the burden of his slave history would always require a cultural anchor for him to fully achieved its outlined objectives. Generally, the Antillean's rebuilding project should take cognizance of his European connection and explore the plethora of benefits inherent in his African heritage as panacea towards making his history burden lighter. The Antillean cannot afford to be rigid with the idea of holistically severing ties with his cultural anchor (Africa) on the one hand and his economic and political masters (France) on the other. In furtherance of this, Antilleans are encouraged to foster and promote cultural ties with Africa, the continent of their ancestors, as a total obliteration of Africa 


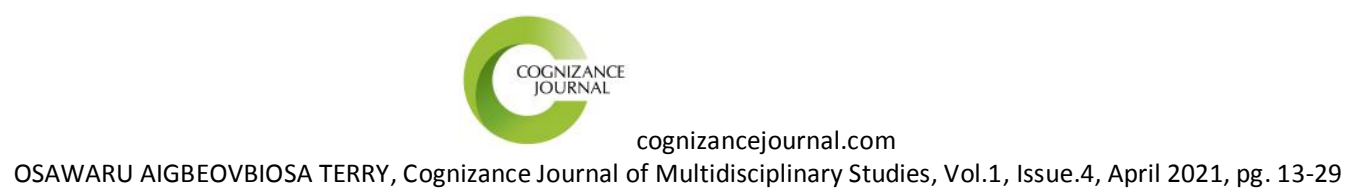

from their existential ascendency would do their distinctive strategies more harm than good and further deepen their history burden. This assertion owes in depth to the fact that the role Africa has to play in the cultural and social development of black Antilleans cannot be overemphasized. In other words, going forward, and to fully understand and redefine their being, it is incumbent on them to halt their desultory tunes and to significantly recognize and acknowledge their African ancestry. Ultimately, Antilleans must also acknowledge the fact that Francophone Caribbean literature definitely has a role to play if they are to eventually resolve the psychological issue of not just getting to know who they truly are, but to define as well who they wish to be. Seeking otherwise to lift the burden of history will be tantamount to waiting for a ship that has long sailed.

\section{REFERENCES}

Antoine, Régis La Littérature franco-antillaise-Haïti, Guadeloupe et Martinique. Paris :

Editions Karthala, 1992.

Brival, Roland La Montagne d'ébène. Paris : J.C Lattès, 1984

Césaire, Aimé Cahier d'un retour au pays natal. Paris : Présence Africaine, 1983.

Condé, Maryse Hérémakhonon. Paris : Union Générale d’Editions, 1976.

Le Roman antillais (2 volumes), Paris : Nathan, 1977.

Corzani, Jack La Littérature des Antilles-Guyane françaises. (6volumes) Fort-de-France :

Desormeaux, 1978.

Fanon, Frantz Les Damnés de la terre. Paris : Maspero, 1961.

Fonkoua, Romouald «Littérature antillaise et histoire : écrire l'histoire des peuples sans histoire» In Notre Librairie, no. 161, mars 2006, pp.104-110. 
cognizancejournal.com

OSAWARU AIGBEOVBIOSA TERRY, Cognizance Journal of Multidisciplinary Studies, Vol.1, Issue.4, April 2021, pg. 13-29

Franklin, John De l'esclavage à la liberté. Paris : Editions Caribbéennes, 1984.

Glissant, Edouard Le Discours antillais. Paris : Seuil, 1981.

Lirus, Julie Identité antillaise. Paris ; Editions Caribbéennes, 1981.

Mokwenye, Cyril Littérature antillaise. Benin-City : Mindex Publishing, 2006.

Black Literature in French. Benin-City : Mindex Publishing, 2009.

Black Literature as Testimony: the Francophone Caribbean's quest for his African

Identity . Inaugural Lecture delivered at the University of Benin, $15^{\text {th }}$ September, 2011.

.......... "Africa as factor in Francophone Caribbean literature" in Topics in Francophone Caribbean Literature, Mokwenye's Edition. pp.106-128, 2013.

Osawaru, Terry "Le Thème de la mort dans la littérature antillaise à travers Dominique nègre esclave de Léonard Sainville in RANEUF, 2011 VOL.1, NO 8,PP.240-248.

Pineau, Gisèle Un Papillon dans la cité. Paris : Editions Sépia, 1992.

Sainville, Léonard Dominique nègre esclave. Paris : Présence Africaine, 1978.

Warner-Vierya, Myriam Le Quimboiseur l'avait dit... Paris : Présence Africaine, 1980.

................ Juletane. Paris : Présence Africaine, 1982. 